\title{
Scholar and beggar : the birth of computer science. (The original erasure of diversity.)
}

\author{
Camille Akmut
}

March 18, 2020

\begin{abstract}
The original act of computer science : the erasure of diversity. A scientist was made acceptable for the benefit of this new, respectable discipline.
\end{abstract}




\section{Introduction - "tamed" beast}

"In how many hagiographies do we encounter [again] the miracle of the tamed wolf, such as Francis of Assisi subjugating the cruel beast of Gubbio!" (trans.)

Le Goff wrote in 'The civilization of the [Western] Middle Ages';

While in art history we often find Saint Jerome depicted with a lion by his side, a tamed lion this time; another example of such representations.

Among many others, this is the theme present in St. Jerome in his Study, or Gerard David's Saint Jerome in the Wilderness ${ }^{1}$.

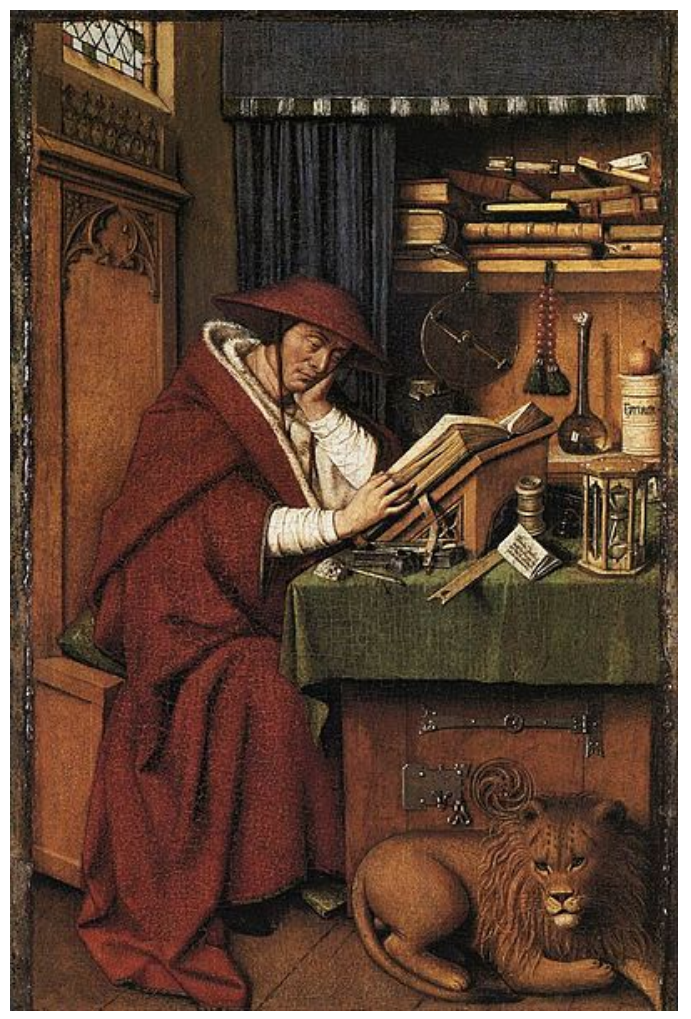

Figure 1: Saint Jerome in his study

Saint Jerome was said to have removed a thorn from the paw of a lion, winning their protection, if not affection.

Hagiographies, or 'the lives of saints', were a genre characterized by highly idealized, partial accounts.

They were both incomplete and overfull at the same time.

\footnotetext{
${ }^{1}$ (Staedel.) Various other representations of St. Jerome with lion exist, and it would be a near infinite task to mention them : Duerer, da Vinci...
} 
In early, and later accounts of Alan Turing we find sure examples of this genre.

\section{A scientific prize, and the life of a saint}

The ACM's ${ }^{2}$ narratives of Turing in the context of its eponymous award are examined again here, before turning to the review of further material. ${ }^{3}$

A major scientific prize for computer science - the so-called "Turing Award" — was first awarded in 1966.

But, its history is inextricable from the preceding erasures of Alan Turing's life : a life lived in full was now rendered only in half for a public in search of respectability.

This was the result of not only the ACM's doing - nothing after Bletchley Park and AI!, but followed a decade of conservative and polite obituaries, by journalists as well as former associates and family members (see later).

They "tamed" Turing (as intellectuals of the Middle Ages had done for their saints). Their purposes were varied :

- to not unsettle the audience of the time (homosexuality was a crime),

- to create a prestigious prize that would bolster a new discipline, namely computer science,

- to preserve a family's good name, reputation ( $c f$. Sara's bizarre account!)

etc. etc..

But, their outcome had one feature in common :

Rather than making a complete portrait of the man-scientist, they fashioned him in a way that was acceptable - to them.

A promotional video by the ACM entitled "The origins of the ACM A.M. Turing Award" offer a poignant illustration of this :

There, the most traditional biography possible of Turing follows the usual steps - birth in 1938, Princeton and Bletchley Park, but suddenly stops after his heroic world war 2 work, and a brief (and grandiloquent) evocation of his artificial intelligence research :

Nothing afterwards! (A series of captions from this material follows.)

But, of course, we know better : the process, the public shame, the hormonal treatment, and death.

They never cared to ask questions such as how the life of a Man influences their work; and never seemed to care much about Turing altogether.

Nothing left of the "sweat and tears" evoked with much honesty by Faulkner in his Nobel Prize address...

This discipline needed an icon more than anything else.

\footnotetext{
${ }^{2}$ Association for Computing Machinery.

${ }^{3} \mathrm{~A}$ first such analysis was already proposed in our prosopography of the Turing Award.
} 
Figure 2: The origins of the ACM A.M. Turing Award by the ACM
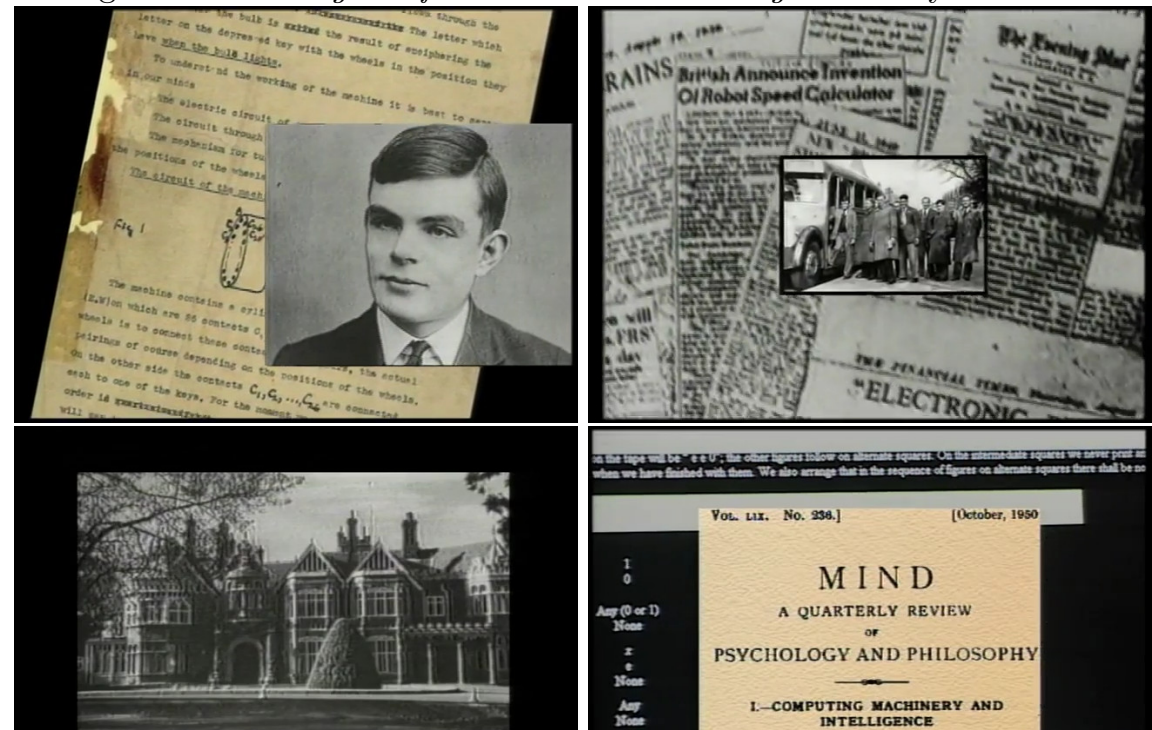

\section{Bletchley Park}
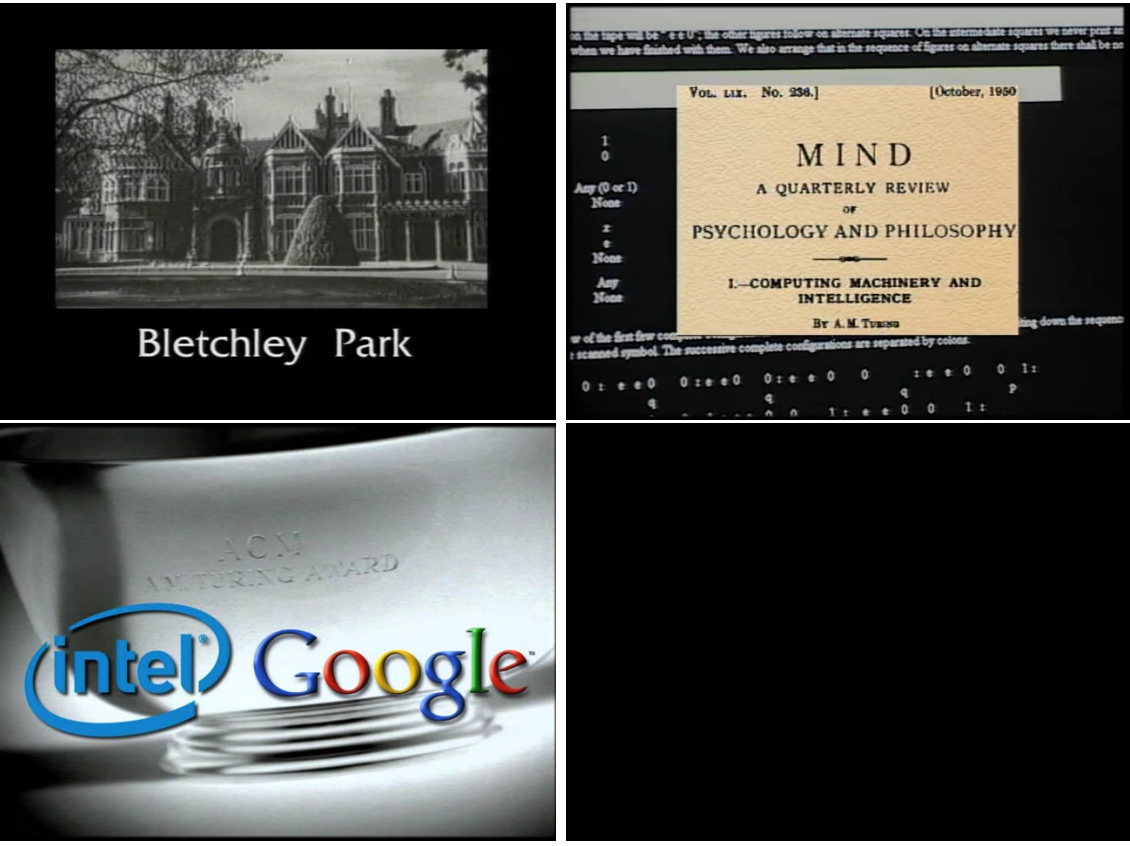

[00:06] 1938, the scientist Alan Turing is (metaphorically!) born.

[00:23] Princeton.

[00:36] Bletchley Park.

[00:56] Artificial intelligence.

[01:48] The Turing Award.

[end] black screen 


\section{Obituaries, and the search for respectability}

We continue this review by turning to various memorial writings published from 1954, marking the year of his death, onwards.

In them, one finds the same preoccupation with respectability (as already found in the making of the Turing Award).

His later work (on the mass of cells) has left "biologists [to] boldly speculate on the possible modes of origins of life on earth. It was a great loss to natural science as well as to mathematicians when, on June 8, at the age of 41, he was found dead in his house at Wilmslow in Cheshire."

- so ended a biography of 1954;

published in the 'Annual Report' of King's College.

No traces here either of the ones he had loved — be it with the big love found in the dialogues of Plato, or the smaller, physical one of the Stoics ${ }^{4}$.

Yet, this was an obituary that was not lacking in various anecdotes and faults.

For, this author neither sparred us Turing's initial failings in mathematics, or the bricks he had constructed in his garden (an early "clever" solution)!

An article published that same year, "An appreciation", similarly went on, and included such generalities as the "los[s] of a great original thinker" and the "loss that science has suffered"...

Meanwhile, The Guardian (then still called The Manchester Guardian) remained equally uneasy about the entire set of circumstances surrounding his death, leaving silent the more personal aspects of this scientist, but relayed a testimony of John, brother of Alan Turing, lawyer :

"[Alan] was always in the best of health (...). He had accepted an invitation from the Royal Society to attend a conversation on June 24."

\footnotetext{
${ }^{4}$ As for Stoics, some of them speculated that philosophers ought to share their wives, in order to eradicate jealousy - among other such things.
} 


\section{Conclusion}

To "consecrate" means to associate with the sacred.

Not much knowledge of the Middle Ages and its peculiar genre of hagiographies is required to understand that, in Turing, these new scholars had found their own "tamed wolf" or lion.

They turned Turing into a saint, so that - by association - they could turn their science into a respectable one.

This was more or less their alchemic formula.

The erasure of diversity in computer science concurred with its creation;

Others will be more courageous in saying that it enabled it.

A new discipline was born, but at what tremendous cost.

Appropriations and rearrangements of Alan Turing and his life marked the early decades of computer science.

Nothing beyond the laboratory! - may be an apt description of them.

It was only by erasing parts of his life, that they could salvage it :

The purpose was to turn Turing into an acceptable figure, so that these gentlemen could be - or feel - respectable themselves.

Writing the history of computer science in this early period means writing the history of an exclusion.

This occured in many ways, not merely in the one that was described here :

For symbolical erasures were soon to be followed by demographic erasures; as can now be amply ascertained from a growing body of statistical studies.

(Numbers so grotesque leave one speechless.)

And, could we be faulted for writing, today, that in order to create this image, this most useful image!, of a saint - the symbolic equivalents of alcohol or bleach were employed :

Used by some to disinfect, just as by others to forget.

But, the image that is perhaps most evocative of the birth of computer science, is it not the one by Petrus Chritus showing both Saint Jerome and Saint Francis together, standing next to the Virgin and Child?

For what more fitting metaphor for this modest, now ambitious discipline than the figure of the scholar outside of his study, and that of the beggar outside of his city... 
REFERENCES

--_. 2018[2017]. "... a prosopography of Turing Award laureates (1966-2016)".

---. 2020. Introduction to the history of computer science. Talk.

"How does one establish a science as a "respectable" discipline?" 10/03. 44 min..

"Identity and responsibility of computer scientists and technologists." 13/03. 36 min..

\section{Archives}

- "The origins of the ACM A.M. Turing Award". ACM. Video.

- The Turing Digital Archive. University of Cambridge. AMT/A/1 and K/5.

King's College, Annual Report, Nov. 1954.

'Dr Alan Turing An appreciation', June 1954.

Manchester Guardian, June 111957.

\section{Iconography}

attr. Van Eyck/circle. "Saint Jerome in his study".

Christus, Petrus. "Virgin and Child with Saints Jerome and Francis". 


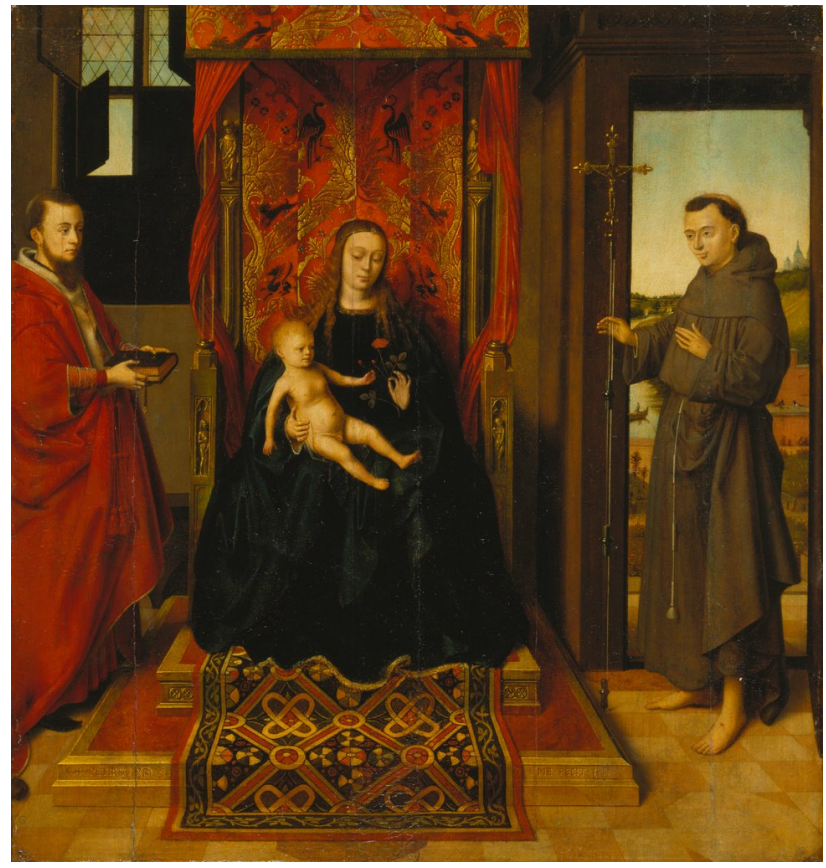

Figure 3: Christus, Virgin and Child with Saints Jerome and Francis

(Staedel Museum, Frankfurt.) 